\title{
COMPORTAMENTO MACHISTA: INATO OU CONDICIONADO?
}

\section{ARTIGO DE REVISÃO}

OLIVEIRA, Janderson Chaves de ${ }^{1}$

CARLETTI, Ednéa Zandonadi Brambila ${ }^{2}$

OLIVEIRA, Janderson Chaves de. CARLETTI, Ednéa Zandonadi Brambila. Comportamento machista: Inato ou condicionado? Revista Científica Multidisciplinar Núcleo do Conhecimento. Ano 05, Ed. 04, Vol. 03, pp. 41-51. Abril de 2020. ISSN: 2448-0959,

Link de acesso: https://www.nucleodoconhecimento.com.br/psicologia/comportamento$\underline{\text { machista }}$

\section{RESUMO}

O presente artigo destinou-se analisar os fatores que levam o comportamento machista a vir a ser inato ou condicionado, bem como a contribuição do mesmo sobre a violência praticada contra a mulher atualmente. Tratou-se de uma pesquisa básica, de abordagem qualitativa, tendo objetivo de pesquisa exploratória. Através de revisão bibliográfica, foi possível constatar os possíveis locais de surgimento do comportamento machista, como ele é mantido e também reproduzido. Além desses pontos, também se analisou a posição hierárquica exercida pelo homem sobre a mulher, assim como as condições que o levam ao medo da perda da masculinidade e também como esse medo pode provocar a perpetuação do comportamento machista vigente na sociedade atual.

Palavras-Chave: Comportamento Machista, inato, condicionado.

\footnotetext{
${ }^{1}$ Graduado em Psicologia.

2 Mestrado em Ciência da Informação. Especialização em Pós Graduação em Informática na Educação. Graduação em Pedagogia.
} 


\section{INTRODUÇÃO}

Ao se falar sobre a soberania exercida pelo gênero masculino sobre o gênero feminino, se fala em longos anos de grandes e numerosas discussões que se perduram até os dias atuais. Atualmente, movimentos feministas põe em questionamento essa soberania, solicitando acima de tudo, igualdade sobre ambos os gêneros para valores salariais e também o direito de exercer funções que, primordialmente, são exercidas apenas por homens, entre outras reivindicações (SILVA, 2006).

Essas reivindicações estão centradas no tempo em que o homem esteve em posição hierárquica superior a mulher. Afinal, em função de sua estrutura biológica, cargos onde a exigência é a força, sempre foram ocupados por esse gênero. Mesmo quando a mulher se mostrava apta a executar a função, o estereótipo de fragilidade imposta ao gênero feminino ao longo da história fazia com que a função fosse negada a ela. A realidade é que o estereótipo de fragilidade mantinha a mulher em uma posição de dependência do homem (SOUZA; GUEDES, 2016).

Essa soberania errônea mantida pela comunidade masculina, ao ser questionada pelo movimento feminista, colocou o homem pela primeira vez em uma posição de temor, onde ele poderia perder o posto que o favoreceu por tanto tempo. Esse medo, fez com que a comunidade masculina organizasse padrões de comportamento para se manter na posição de poder, padrões que os tornassem mais masculinos. Entretanto, é nesse padrão de comportamento, onde a soberania é evidenciada, que o comportamento machista pode surgir (SILVA, 2006).

O comportamento machista, sendo ele $\mathrm{o}$ ato de se posicionar contra a igualdade de direitos e deveres entre gêneros sexuais, tem por objetivo menosprezar e qualificar como ruim qualquer comportamento feminino. Ele, assim como outros comportamentos humanos, provoca discussões a muito tempo no que se refere ao seu surgimento. A questão principal que tange esse comportamento é se sua origem é totalmente inata ao nascer, ou seja, hereditária, ou se esse comportamento é completamente aprendido, condicionado através de estímulos lançados de forma 
contínua pelo ambiente em que o organismo, no caso o ser humano, está inserido (SALGUEIRO, 2016).

Por isso, ao se tentar compreender se o comportamento machista pode ser totalmente condicionado por conta dos processos culturais e socais em que o indivíduo está exposto e não adquirido de forma hereditária, é possível criar estratégias que proporcionem o condicionamento de novos comportamentos que não sejam prejudiciais ao convívio harmônico de homens e mulheres na sociedade, mudando assim uma realidade de medo e angústia vivido nos dias atuais pela população feminina (MEDEIROS; MOREIRA, 2007).

Afinal, os tipos de violências causadas pelo comportamento machista como as violências físicas, psicológicas, verbais, morais e sexuais possui grande impacto na segurança da mulher na sociedade. Contudo, compreender de onde provém o comportamento é extremamente necessário para criação de meios que possam combate-lo, por isso, nos próximos passos da leitura dessa pesquisa, você poderá compreender os fatores que giram entorno do surgimento desse comportamento e também suas possíveis consequências (PINHEIRO, 1994).

Sendo assim, esta pesquisa de natureza básica, de abordagem qualitativa, com o objetivo de pesquisa exploratória, por meio de revisão bibliográfica visa demonstrar os fatores que levam o comportamento machista a ser inato ou totalmente condicionado conceituando o comportamento condicionado através de estímulos do meio ambiente, verificando os fatores que levam ao questionamento se o comportamento machista é inato ou condicionado, demonstrando as consequências do comportamento machista na rotina da população feminina e analisando os tipos existentes de comportamento machista e sua relação com os tipos de violências (GIL, 2002; PRODANOV; FREITAS, 2013).

\section{O COMPORTAMENTO CONDICIONADO}

Quando falamos em condicionamento do comportamento pavloviano por exemplo, falamos no processo ou no procedimento pelo qual os organismos aprendem novos 
reflexos através de estímulos lançados pelo ambiente em que ele vive. Sendo assim, é possível compreender que cada organismo, inclusive o ser humano, tem a capacidade de aprender, ou seja, de ser condicionado a realizar novos comportamentos por meio da inserção de estímulos de forma contínua que provocará o surgimento do novo comportamento que ao nascer não fazia parte do seu repertório comportamental (MEDEIROS; MOREIRA, 2007).

Por isso, ao se pensar no comportamento obtido pelo organismo através da interação com seu meio, pode-se definir que os diversos tipos de interações existentes provocam diferentes classes de comportamentos nos organismos. E, para que esse processo aconteça, é necessário que exista uma relação totalmente funcional entre o comportamento do organismo e o ambiente em que ele vive. O que leva a compreender que a manutenção dos comportamentos dos organismos acontecerá através de suas consequências, sendo essas benéficas a ele ou não, pois o comportamento é função de variáveis externas (TODOROV, 2012).

Se levarmos em consideração esse conceito de comportamento condicionado e concluirmos que grande parte dos comportamentos provém da interação entre o organismo e seu meio ambiente, compreenderemos que tanto o ambiente quanto o organismo sofrem alguma alteração no seu estado original quando um novo estímulo é adicionado. Um grande exemplo dessa afirmação são as glândulas sudoríparas que reagem quando são estimuladas pelas alterações de temperatura do ambiente. Desse modo, as ações do organismo não são possíveis sem sua relação com o ambiente (TODOROV, 2012).

Porém, uma simples observação de grupos humanos nos leva a entender que as construções físicas como a cor dos olhos, da pele e a altura, por exemplo, são construídas exclusivamente por fatores biológicos que demonstram grandes diferenças de um ser para outro, assim como os comportamentos humanos que também demonstram grandes diferenças de um ser para outro, o que leva a indagar se as diferenças apresentadas nos comportamentos humanos são determinadas apenas por fatores culturais ou se também são influenciadas por fatores genéticos, ou seja, um comportamento que pode vir a ser inato-adquirido (PINHEIRO, 1994). 


\section{COMPORTAMENTO INATO-ADQUIRIDO E SUAS CONTRADIÇÕES}

Para a perspectiva nativista, que se contrapõe a essa ideia de comportamento obtido através da interação organismo com seu meio ambiente, a inteligência humana, bem como sua personalidade e traços físicos, já estão formados quando o indivíduo nasce, por conta de seus genes. Os adeptos dessa ideia nativista, acreditam que um indivíduo nasce inteligente porque seu pai ou sua mãe já possuíam essa mesma característica em sua carga genética, o que leva a entender que o posicionamento nativista acredita que o comportamento humano, ou uma grande parte dele é inato, isto é, cada ser humano já nasce com tendências ou predisposições que não podem ser mudadas através do condicionamento (PINHEIRO, 1994).

Ao se pensar que o comportamento é inato e não aprendido, entende-se que o indivíduo nasce com comportamentos considerados disfuncionais pela sociedade, como o machista e o violento e não que ele os adquire quando exposto a um ambiente onde os padrões comportamentais mais comuns são esses. $\mathrm{O}$ indivíduo, ao interagir com um ambiente onde o comportamento machista é comum, acaba apenas reproduzindo os mesmos, porque a interação com o meio apenas intensificou o padrão de comportamento contido no seu código genético e não o provocou (PINHEIRO, 1994).

Porém, existem erros no pensamento nativista. Um deles é que através das células sexuais são passadas as informações genéticas e não características comportamentais. Não se pode afirmar que através dos genes um indivíduo se tornará músico ou um grande cientista. Os genes irão criar a base para os traços culturais, mas não irão forçar o desenvolvimento de um traço em particular. Outro erro dessa perspectiva é o significado da palavra inato. As características físicas de um indivíduo ao nascer são consideradas congênitas, ou inatas, o que não quer dizer que é hereditário, pois existem características inatas que são derivadas de fatores ambientais da gestação como as alterações no desenvolvimento do feto por ingestão de álcool pela mãe (PINHEIRO, 1994). 
Acerca disso, as contradições que a perspectiva nativista demonstra, evidencia que a genética tem participação em características físicas de um indivíduo, ela poderá determinar sua força física, sua altura, cor dos cabelos ou sua predisposição em desenvolver uma doença congênita, mas não terá influência direta na criação de um comportamento considerado disfuncional pela sociedade (PINHEIRO,1994). Serão os fatores culturais do ambiente que condicionaram formas e padrões de comportamentos humanos, cada ambiente será favorável a um tipo de comportamento em específico e cada indivíduo pertencente ao mesmo o reproduzirá criando assim uma identidade sexual masculina baseada nos padrões comportamentais do ambiente (TODOROV, 2012).

\section{IDENTIDADE SEXUAL, CRISE DA MASCULINIDADE E A MANUTENÇÃO DO COMPORTAMENTO MACHISTA}

O que pode explicar um ambiente favorável à interação e ao condicionamento do comportamento machista é a grande preocupação que parte da população masculina possui com a feminilização dos homens, ou seja, uma perda da masculinidade caracterizada por atos julgados como sendo exclusivamente femininos. Isso faz com que eles invistam e criem para si, papéis ou traços que representem o que é uma condição masculina correta. Outro ponto ou questão que explica a manutenção desse comportamento, é que com o crescimento dos movimentos feministas e a proposta de uma discussão no que se refere aos papéis sociais masculinos e femininos, fez com que o papel da mulher ficasse mais delimitado na sociedade, o que levou a uma nova ressignificação do papel masculino, levando o homem a perda do lugar de dominador que ele exercia sobre a figura feminina até então (SILVA, 2000).

Outro ponto acerca da manutenção do comportamento machista é referente a identidade sexual que é imposta pelos pais, e também cobrado de forma direta e por vezes de forma indireta pela sociedade, fazendo com que a heterossexualidade seja um único modelo normativo e correto de orientação sexual. Nesse caso, os pais e a sociedade agem como o meio que condiciona e mantém a reprodução do comportamento machista. Porém, a feminilidade e a masculinidade existem em todas 
as pessoas em graus totalmente diferentes, mas a opressão sofrida quando um homem se mostra com grau de feminilidade maior, o obriga a reprimir esses traços e a reproduzir com maior intensidade comportamentos considerados masculinos (SILVA, 2006).

Quando falamos desse comportamento de reprimir traços femininos, estamos tratando do medo da homossexualidade. Esse medo é mais um ponto que leva a agravar a crise da masculinidade e por consequência a manter o comportamento machista. Quando o homem perde as fronteiras do que é masculino e do que é feminino, ele se apavora, o levando não só ao medo de perda do poder sobre o feminino, mas também gerando o medo da homossexualidade, sendo esse medo, por vezes, mostrado de forma agressiva, o que qualifica a homofobia, que é mais um comportamento derivado da interação com o meio (SALGUEIRO, 2016).

Ao falar da crise da masculinidade, talvez estamos tratando do que mantém o comportamento machista vivo. A crise se configura por meio do conflito de identidade, acontecendo quando o homem tenta se manter em um modelo de gênero hegemônico, ou seja, de autoridade soberana baseando-se nos modelos que já são tradicionais e também nos novos modelos de masculinidade. Porém ao tentar se manter nesse modelo, ele percebe a impossibilidade de sustentar essa hegemonia, e é a partir desse momento que a crise se instaura fazendo com que a insegurança masculina venha a se manifestar através do comportamento machista que, na maioria das vezes, é violento (SILVA, 2006).

Então, sabendo que o comportamento machista provém da interação com o meio em que o organismo se encontra inserido, entende-se que o mesmo deriva do contato entre o modelo normativo do que se é definido como masculino e da tentativa falha de se manter um modelo hegemônico de masculinidade. A exposição do ser humano a um meio onde o padrão de comportamento é ser o oposto do feminino faz com que o condicionamento do comportamento machista se mantenha dando ao ser a capacidade de se definir como homem completamente masculino (TODOROV, 2012). 
Para que essa definição de homem completamente masculino aconteça, de acordo com o modelo de gênero hegemônico, é necessário ter características masculinas específicas como o não chorar, não ser mulher, não ser homossexual, não ser fraco ou covarde, mas ser forte, corajoso, pai, heterossexual, agressivo e líder. Todas essas características constituem o papel social que o homem deve exercer. Sendo assim os ideais tradicionais, ou seja, os estímulos que o meio insere para condicionar o comportamento masculino remetem sempre ao não feminino, pois esse feminino é tido como ruim, fraco e subordinado ao masculino que é forte, másculo e bom, estabelecendo assim uma hierarquia e mantendo o domínio dos homens sobre as mulheres (SILVA, 2006).

Além da hierarquia, os ideais tradicionais deixam explícitas as divisões existentes entre o mundo produtivo dos homens e o mundo reprodutivo das mulheres, porém com o atual enfraquecimento desses ideais masculinos, as mulheres estão ganhando espaços no mundo produtivo, mas o ganho desses espaços não significa, necessariamente, que as tarefas que foram designadas de forma primária para as mulheres, estejam sendo dadas aos homens, pelo contrário, as mulheres continuam, em sua maioria, com os serviços domésticos, com a criação dos filhos e manutenção da dinâmica familiar ao mesmo tempo que trabalham fora e lutam pelos seus próprios ideais, evidenciando que o machismo ainda está vivo, mas se mostrando a cada dia de formas diferentes (SOUZA; GUEDES, 2016).

\section{CONSIDERAÇÕES FINAIS}

Ser homem ou ser mulher está totalmente correlacionado com a cultura do lugar onde se vive. No Brasil, o gênero feminino ou masculino não determina apenas a questão de sexualidade, designa também a posição do indivíduo na sociedade. A grande verdade é que o machismo não está somente relacionado a educação, o ser humano pode sim adquirir e ampliar todo o seu conhecimento, entretanto, a cultura machista não mudará em função desse engrandecimento, porque ela está presente na sociedade em si e não somente em uma parte dela. Sendo assim a ampliação de conhecimento não impede que a cultura machista se mantenha. 
Essa cultura machista era muito mais evidente no século XIX, pois nessa época existia uma nítida separação entre o controle público e o privado, em que os homens faziam parte do campo público pois exerciam a posição de provedor da família, enquanto as mulheres faziam parte do campo privado porque cuidavam do lar enquanto o marido proporcionava o sustento financeiro. Atualmente, não vemos essa separação entre controle público e privado de forma tão explícita, a mulher continua cuidando da prole enquanto constrói uma carreira profissional ao mesmo tempo em que o homem proporciona maior sustento familiar com sua função profissional de maior remuneração. Veja bem, a separação ainda existe, mas a logística com que ela é evidenciada mudou por conta da inserção da mulher no mercado de trabalho.

Sendo assim, fica claro que o comportamento machista está baseado em fatores socioculturais e históricos, ele está voltado a satisfazer os interesses tanto de exclusão quanto de dominação da mulher. Porém repreender e condenar o machismo não é o suficiente, afinal é possível notar seu trabalho silencioso e escondido no discurso de igualdade entre os gêneros. É importante salientar, que a resistência do comportamento machista está baseada no desconforto sentido por alguns homens em relação a liberdade sexual atual das mulheres, mesmo que eles preguem o discurso de igualdade, em suas mentes o medo de perder o domínio sobre o gênero feminino fala mais alto e leva a reprodução do comportamento machista na maioria das vezes.

O objetivo dessa pesquisa se centrava em identificar os aspectos que comprovavam o surgimento do comportamento machista como sendo condicionado ou inato, e ficou evidente que de inato o ser humano carrega suas características físicas e que seus comportamentos derivam da sua exposição com os aspectos culturais do ambiente. Porém essa pesquisa não pode se findar aqui, afinal, atualmente o medo da violência sexual atormenta a vida da população feminina, já que não existe hora ou lugar para que um estupro se concretize. A hierarquia entre os gêneros além de colocar em jogo a segurança das mulheres em geral, primordialmente, tira também os direitos a igualdade salarial e a ocupação de cargos de maior valor. Por isso, ainda existem pontos a serem desbravados como o prazer que a soberania sobre a mulher proporciona ao homem e também os privilégios que ela traz. Além disso, o 
comportamento machista vem beneficiando o aumento das taxas de feminicídio em nosso país, o que demonstra a urgência nos estudos desse comportamento que busquem a sua extinção.

\section{REFERÊNCIAS}

GIL, Antonio Carlos. Como elaborar projetos de pesquisa. In: Como classificar as pesquisas?. São Paulo: Editora Atlas, 4. ed. Cap. 4, p. 41-57, 2002.

GUEDES, Dyeggo Rocha; SOUSA, Luana passos de. A desigual divisão sexual do trabalho: um olhar sobre a última década. Estud. av, São Paulo, v. 30, n. 87, p. 123139, ago. 2016.

$<$ http://www.scielo.br/scielo.php?script=sci_arttext\&pid=S0103$40142016000200123 \&$ Ing=en\&nrm=iso >. Acesso em 04 junho 2019.

MEDEIROS, Carlos Augusto; MOREIRA, Márcio Borges. Princípios básicos de análise do comportamento. Porto Alegre: ed. Artmed, 2007. Cap. 2, p. 30-46.

PINHEIRO, Marta. Comportamento humano: interação entre genes e ambiente. Educ. rev, Curitiba, n. 10, p. 53-57, dez. 1994. Disponível em $<$ http://www.scielo.br/scielo.php?script=sci_arttext\&pid=S0104$40601994000100007 \&$ Ing=en\&nrm=iso >. Acesso em 23 maio 2019.

PRODANOV, Cleber Cristiano; FREITAS, Ernani Cesar de. Metodologia do trabalho científico: Métodos e Técnicas da Pesquisa e do Trabalho Acadêmico. In:

Pesquisa Científica. Novo Hamburgo: Feevale, $2^{\underline{a}}$ edição, cap. 3, p. 41-118, 2013.

SALGUEIRO, José Estevam. Homossexualidade masculina: comportamento, orientação e identidade. Psicol. teor. Prat, São Paulo, v. 18, n. 1, p. 60-74, abr. 2016. Disponível em <http://pepsic.bvsalud.org/scielo.php?script=sci_arttext\&pid=S1516$36872016000100005 \&$ lng=pt\&nrm=iso >. Acesso em 26 maio 2019.

SILVA, Sergio Gomes da. Masculinidade na história: a construção cultural da diferença entre os sexos. Psicol. cienc. Prof, Brasília, v. 20, n. 3, p. 8-15, set. 2000. 
Disponível em <http://pepsic.bvsalud.org/scielo.php?script=sci_arttext\&pid=S1414$98932000000300003 \&$ Ing=pt\&nrm=iso $>$. Acesso em 23 maio 2019.

SILVA, Sergio Gomes da. A crise da masculinidade: uma crítica à identidade de gênero e à literatura masculinista. Psicol. cienc. Prof, Brasília, v. 26, n. 1, p. 118131, mar. 2006.

Disponível

em

<http://pepsic.bvsalud.org/scielo.php?script=sci_arttext\&pid=S1414-

98932006000100011\&lng=pt\&nrm=iso >. Acesso em 23 maio 2019.

TODOROV, João Claudio. Sobre uma definição de comportamento. Perspectivas, São Paulo, v. $\quad 3$, n. $\quad$ 1, p. 32-37, 2012. Disponível em <http://pepsic.bvsalud.org/scielo.php?script=sci_arttext\&pid=S2177$35482012000100004 \&$ Ing=pt\&nrm=iso $>$. Acesso em 23 maio 2019.

Enviado: Março, 2020.

Aprovado: Abril, 2020. 